IRSTI 16.21.33

\author{
Abdurishid Yakup ${ }^{1}$, Alkebaeva D.A. ${ }^{2}$, Zaurbekova LZh. ${ }^{3}$ \\ ${ }^{1}$ Professor of Minzu University, China, Beijing \\ ${ }^{2}$ Doctor of Philology, Professor of Al-Farabi Kazakh National University, Kazakhstan, Almaty \\ 32-year DoctoralStudent of Al-Farabi Kazakh National University, Kazakhstan, Almaty, \\ e-mail: yakup@bbaw.de, alkebaeva@mail.ru, liza91_1604@mail.ru
}

\title{
STYLISTIC CATEGORY OF ACCENTUATION IN ART TEXTS
}

This article addresses the concept of style and stylistic categories. In particular, it describes the stylistic category of accentuation. Stylistic accentuationcategories are found in all functional styles. Their functions in every style are considered. However, in the study and analysis of the stylistic accentuationcategories, it has become known that they exist in art texts as well. The stylistic categories of accentuation are conveyed not only through such linguistic unitsas intonation, word combinations, and sentences, but also through paragraphs and dialogues. Afterwards they turn into aphorisms. By analyzing works of art, the role of the stylistic category of accentuation and its importance in the text creation have become known.

Key words: style, stylistic connotation, stylistic accentuation category, art text.

$$
\begin{gathered}
\text { Аблуришид Якуп }{ }^{1} \text {, Алкебаева А.А. }{ }^{2}, \text { Заурбекова А.Ж. }{ }^{3} \\
\text { 'Минзу университетінің профессоры, Қытай, Пекин қ. } \\
\text { әл-Фараби атындағы Қазақ, ұлттық университетінің 'профессоры, } \\
\text { ф. ғ. А., }{ }^{3} 2 \text { курс докторанты, Қазақстан, А^маты қ., } \\
\text { e-mail: yakup@bbaw.de,alkebaeva@mail.ru, liza91_1604@mail.ru }
\end{gathered}
$$

Көркем мәтіндегі стилистикалық акценттік категория

Мақалада стиль және стилистикалық ұғымдар қарастырылады. Стилистикалық категориялар ішінде арнайы акценттік категорияны қарастыру мақсатқа алынды. Акценттік категориялар барлық функционалды стильдерде ұшырасады. Стилистикалық акценттік категориялардың әр стильдегі қызметі қарастырылады. Әсіресе көркем мәтіндердегі стилистикалық акценттік категориялар талданды. Сонымен қатар стилистикалық акценттік категория бір тілдік бірлік айналасында, интонация, сөз тіркесі, сөйлемдер арқылы ғана жасалмайды. Абзац, диалогтарда да кездеседі. Кейіннен тұрақты тіркестер мен афоризмдерге айналып кететіндігі анықта^ды. Көркем шығармаларды салыстыра талдап, мәтін түзуде стилистикалық акценттік категориялардың маңызы, стилистикалық сипаты ашылды.

Түйін сөздер: стиль, стилистикалық коннотация, стилистикалық акценттік категория, көркем мәтін.

Абдуришид Якуп ${ }^{1}$, Алкебаева А.А. ${ }^{2}$, Заурбекова А.Ж. ${ }^{3}$

${ }^{1}$ профессор университета Минзу, Китай, г. Пекин

${ }^{2}$ Казахский национальный университет имени аль-Фараби, А.ф.н., профессор, Казахстан, г. Алматы

${ }^{3}$ Аокторант II курса Казахского национального университета имени аль-Фараби, Казахстан, г. Алматы e-mail: yakup@bbaw.de,alkebaeva@mail.ru, liza91_1604@mail.ru

\section{Стилистическая категория акцентности в художественном тексте}

В статье рассматривается понятие стиля и стилистических категорий. В особенности описывается стилистическая категория акцентности. Стилистические акцентные категории встречаются во всех функциональных стилях. И рассматриваются его функции в каждом стиле. ОАнако, в ходе исследования и анализа стилистических категорий акцентности стало известно, что они существуют и в художественных текстах. Стилистические категории акцентности передаются не только через такие языковые единицы, как интонация, словосочетания, предложения, но и 
через абзацы и диалоги. И в будущем превращаются в афоризмы. Анализируя художественные произведения, стала известна роль стилистических категорий акцентности и его значимость в создании текста.

Кмючевые слова: стиль, стилистическая коннотация, стилистическая акцентная категория, художественный текст.

\section{Introduction}

Language is a system. Meanwhile, the system is a set of units which form a logical connection bya clearly defines type. The system in any language has three distinctive features: separability, integrality, and connectivity. These three features help styles get grouped, separated, and connected. The concept of style is polysemic. It is used in many branches of science, moreover, itacquiresdistinctly personal meaning. Style is anexclusive phenomenon. Its other definitions claim it to be considered as constant repetitions.

Stylistics,which consider style in detail, is known to be a new branch of linguistics. The cornerstone of modern stylistics can be traced back in antique poetics and rhetoric. The development of stylistics in the XVIII centuries was hugely influenced by Lomonosov's theory of the «Three Calm» and «Rhetoric» (1748).

The concept ofstylistics appeared in the works of German romanticists at the beginning of the XIX century. The aimto give stylistics scientific credence is observed in the work «Philosophy of Stylistics» by G. Spencer (1852) and H. Steinthal (1866). By virtue of the research by AN Veselovsky (Excerpts on the History of Epithet, 1895) and AA Potebnya historical stylistics laid its foundation. Stylistics in modern linguistic began its remembrances at works byCharles Bally (Traité de Stylistique Française (French Stylistics), 1909).

In Russia, in the $20 \mathrm{~s}$ of the $20^{\text {th }}$ century, stylistics was regarded as the backbone of the culture of speech. Nevertheless, stylistics as anindependent discipline in Russian linguisticswas scientifically justified by the conceptual ideas of VV Vinogradov (Vinogradov, 1963:150).

Stylistics, in its turn, is divided into general, individual, comparative, functional, coding and decoding stylistics.

General stylistics delves into the concept of style, functional styles, principles ofword usage, and suchlike categories common to all languages in broader terms. Individual stylistics examines the categories of a specific language. Comparative stylistics is oriented towards comparing and analyzing stylistic phenomena in a range of languages. Func- tional stylistics involves functional styles. In more exact terms, this type of stylisticsencapsulates linguistic units lying beyond the text.

A text means to be linguistic forms selected by a speaker according to his or her personal purpose. Coding stylistics is concerned with the idea of a person delivering the text, where as decoding stylisticsanalyzesaspects that affect the textrecipient.

In this way, stylistics is one of the branches of linguistics that looks into the functional styles and various expressive devices and phenomena of language.

We have mentioned that the concept of style, which is the studys ubject of stylistics, does have a myriad of definitions. In fact, the word «style» originates from Latin and means a tool for writing. Later, in connection with the change of its meaning, it was used as a writing technique and benchmark belonging tothe disciplines of rhetoric.

In everyday life, the word «style» is widely used. In Kazakh, «style»is used interchangeably with «fashion(able)». For example, stylish/fashionable clothes, furniture, caretc. At the same time, the Russian «стиль жизни» (the style of life) is perceived as a lifestyle of a particular group. There was a time when «стиляги» [stilyagi] (meaning «style hunters», «hot dressers») was a prominent social group. Style can be good and bad, elevated, high, romantic, realistic, and classic. From this perspective, the word «style» first and foremostmeans'distinctiveness', 'selected'. For example, any person chooses certain linguistic unitsto express his or her words and thoughts. That is, the distinctive features of linguistic units depend on their purpose and the situation. In colloquial speech:-Hey, buddy, what's the matter? - can be used as - Buddy, spell the matter out for me!Likewise, the phrase "I'm listening» has other options like «I'm all ears», «Yes, you have my undivided attention» and «You have my attention». These phrases are selected directly depending on the situation and speaker's level of education, adherence to speech etiquette, andtarget addressee of the speech. Even speaker's voice rhythm andtonechangesrefers to an individual style.

The concept of style is not the only matter that stylistics covers; it is a science covering:

1. Expressive linguistic units; 
2. Several synonymic chains and devices expressing one and the same idea;

3. Different emotional tones and speech forms in language;

4. System of stylistic devices;

5. Author's individual style and so on.

Nowadays, linguists use the term «style» in the sense of functional style. The functional style is linguistic unitsactively usedas variations of linguistic units in specific circumstances. Styles are a linguistic phenomenon, but theytend to evolve under the influence of extralinguistic factors. The style is a great contributor to the implementation of certain language services (communication, information, impacting). "Style is an outside appearance of the workcontent, which is manifested in all lexical, syntactic, genre-and-composition and other levels of an art text»- researcher B.Sh. Baymusaeva (Baymusaeva, 1994:14) defines. In the art work, style is not about original tone and color of certain words, but about interrelation between texts.

Style demonstrates the uniqueness of author's creativity along with consistency and integrity of the internal content of the work. Each style can perform all three language functions, but one or two of them are the primary ones. Furthermore, in specificlinguistic situations, the function of style is particularly visible. Five styles (colloquial, publicist, scientific, art, official-and business)of which we have knowledgeuse all linguistic units. While some linguistic units can be used in one and only style. For instance, the idiom (to) sow the seeds of discord is typical of the literary style only.

In stylistic devices (resources), style appear as a set of monosemantic linguistic units. Any linguistic unit is a stylistic device. Stylistic devices are directly related to synonymity (lexic, grammatical, wordformation). Apart from synonymity,stylistics also includes stylistic figures and tropes.If the change of word'smeaning stylistically is intrinsic to tropes in order to have an exceptional effect when speaking, then stylistic figures represent the correct combination of words.

Stylistic colouring(stylistic connotation) is a phenomenon involving all linguistic units: morpheme, word-formation, vocabulary, morphology, and syntax.

Connotation, being a stylistics category of expressive evaluation, is the main way to form a stylistic normative. The fact that the main descriptors of connotation is the ability to derive additional meaningfrom denotative meaning supposes emotional and expressive evaluation. Researchers refer as main descriptors of connotation coming out from different situations the following:

Situational-psychological: generating ironic laughter, euphemistic (in compulsive meaning);

Social-linguistic: slang types (in colloquialspeach, in literary language);

Newly emerged connotations in culture science.

Researchers highlight that the original denotationmeaning of some endings also changes to connotation meaning. As a result of such scientific opinions, it can be said that in every style, stylistic connotations can be encountered in endings, word combinations, and sentences.

Stylistic connotation is expressive and stylistic qualitiesused in addition to material-logical and grammatical meanings; it is a manifestation of stylistic connotation. There are many types that determine the nature of stylistic connotation amongst main concepts and categories of stylistics.

The use of stylistic tone and stylistic normative reflecting the properties of stylistic connotation is a natural phenomenon. If the manifestation of connotation in individual linguistic units undoubtedlydepends on itsnatural strength and depth, its main function results in stylistic manner and pragmatic purpose. Stylistic colouring is an extra meaning of a word that gives a unique stylistic effect beyond the context. The stylistic colouringof polysemouslinguistic units announces not only material-logical nature, but stylistic technique that adds extra meaning clearly shows a pragmatic «action» in the latent meaning of the word.

Stylistic colouring can be seen not only through expressive-emotional connotation, but also via various extalinguistic factors. More precisely, the scope of relationship, features of functional styles, genre types, content and form of speech, as well as communication between the addresser and the addressee, author's attention to the matter and phenomenon can bear its features (Alkebaeva, 2014:31)

Stylistic connotations can be emotional-expressive (evaluative) and functional-stylistical.

Emotional-expressive connotations are caused as a result of personalview and attitude toward a particular matter. It is seen in all areas of linguistics and all types of styles. However, it is widely reflected in lexical units. For example, Жәке [Zhake - diminutive for most names in Kazakh beginning with Zh], Бәке [Bake-diminutive for most names in Kazakh beginning with B], үüшік [úıshik - a shack], көлшік [kólshik - a puddle], aķcaycaķ [aqsaýsaq-a kidglove], есерсоқ [esersoq - a madcap], байсымақ [baisymaq-a new-rich] etc. are based on generally acceptedviewpointrelated to people and matters. At 
the same time, the pragmatic value is exceptionally evident in emotional-expressive connotations. Stylistic connotations have a great role in delivering addresser's message. A fine example of this is the word-of-mouthphrase «көшпелі құазақ»» («nomadic Kazakh») or «көпшелі өмір сүру салтыл» («nотаdic life style») dating from ancient times. This concept is used in publicistic, colloquial, literary, and scientific styles. There are a plenty of essaysand historical data about nomadic lifestyle. According to historical evidence, the order implying the change from nomadic to sedentary lifestyle in the Kazakh land was issued in 1924. This is a historical fact. Whilst in today's everyday life it iswidely known that the phrase "We are nomadic Kazakh after all» is used quite often in a sarcastic manner. Notwithstanding that centuries had gone by sincethe Kazakhschanged to a settled way of life, if any person moves from one place to another, people often say «What can we do? We are Nomads after all.» This historic conceptis gradually being replaced by arolling-stone lifestyle. The flow of time and changes in the political and social situation are replacing the nomadic life to the rolling-stone lifemaking everyone to move often or be unwilling to settle down in one place. That is to say, the expressive connotations may change over time. They create a variety of word combinations and linguistic units around a concept.

Functional-stylystical connotations are reflected in the linguistic units used only in a specific social environment. Often, scientific and literary styles prevail.

Apart from concepts such as stylistic connotations and devices,stylistics also includes stylistical (functional, semantic-stylistical)categories. Stylistical categories are divided into evaluation, accentuation, hypothesis, dialog, author's image, text category etc. Among them,we are going to settle upon stylistic accentuation category.

The stylistic accentuation category requires attention in terms of meaning of linguistic units; itdemonstratesto the addressee the reliability of author's vision, thereby ensuring that the recipient and the listener have a common understanding. The addresser convinces the listener of the truth to his or her main textual information. (Alkebaeva, 2014:37)

The stylistic accentuation category is a semanticstylistical category that expresses certain fragments of text and speech as the most important ones. The accentuation is also reflected in the speaker'sspeech. The addresser determines the important components of his or her speech through the stylistic accentuation category and helps the addressee to perceive the speech subjectively and objectively.
Units showcasing the stylistic accentuation category (accentuators): logical accent, lexicalsemantic strengthening words (primarily, importantly, extremely, specifically, firstly), intensifiers (too, too much, only), comparative degree of qualitative adjectives (better, stronger), modal words (required, needed, obligatory). Besides, the stylistic accentuation is ensured byfigurative-sensewords and metaphors. For example, «Poor man.... May he rest in peace. Only Creator knows when to end his servant's life... He had to have been a little younger than me.

First of all, the mother sitting there cannot speak Kazakh, on the contrary, she's not to blame.

Suddenly, (he) took it to such a strong and high pitch, then stopped, and letthe dombra speak again.

Thereis treasure underthisground. In our $\mathrm{Ka}$ zakhstan, there are very rare elements. So many precious stones! Pearls, corals, marbles, sapphires, diamonds - everything you need»(«Guests» by $\mathrm{T}$. Abdikov)

"At the back ofOskemen, on the right side of Bukhtarma, there isworld-known Altay. From the sunny side of that Altay, towards Mecca, rushes down wards roaring Kurshim to flow into Irtysh.

Mamyrbai's Aqbilek, Aqbilek - his young child, his Sun and Moon, his beautiful daughter-in her flowy white dress, jingling golden earrings and silver hair pendants brought homeher red and green blankets dusted off» (Aimauytov, http://www.iref. kz/zh-sipbek-aymauyitov-a-bilek-romanyi-tolyi-n$\mathrm{s}-\mathrm{a} /$ )

"Tortai exceptionally loved me among others. He had been all over.

Unlike us, his specific trait was reading booksfrom morning to night. Tortai, who indiscriminnately read every book that came into his hands, was our Mr. Know-It-All, our wise man we listened to in wide-mouthed astonishment.»( Bokei, http://sauap. org/wp-content)

Stylistic accentuation categories are found in all functional styles. However, it is manifested in each style uniquely. It is shown in the scientific style with the above-mentioned syntactic devices, in the publicistic, art-literary style - neutral accentuators, whilst intonational accents are important in colloquial speech. For instance, in science articles, the focus on the particular issueis felt throughpunctuationshowing intonation. This stylistic accentuation category is seen even inarticle or essay headings. A sentence or a paragraph with the stylistic accentuation category may turn into an entire aphorism. «For Abay, without doubt, the first man of this makein the Kazakh land isDulat. 
Social sorrow in Dulat is a new state, a new spirit, that has never been in the Kazakh mindset.

Grief in Abay starts with a man.»("Abay and Dulat»by Tursynzhan Shapay)

"Those who first practiced Abay studiesisthe Kazakh intellectual class at the beginning of the XX century.» ("Alash and Abai» by U. Abdimanuly)

"Makhambet Otemisuly is a man who fought for freedom and equality of the Kazakh people to the last drop of his blood with his spear and sublime liberation poetry, and a warrior, a poet who even sacrificed his own lifein this fight» (from the article «Revelation about Makhambet Otemisuly»)

The stylistic accentuation category is a set of accentuators that grouped for the purpose of delivering to the addressee text categories in the form of one-levellinguistic units which areimportant in terms of meaning. A text which is created usingthe stylistic accentuation category helps to adjust the relationship between the author and the addressee and to have the author's concept adequately perceived by the addressee. The addresser can communicate his or her intent to the addressee through accentuators, thereby demonstrating the novelty and relevance of the information provided. Stylistic accentuation categories differ in each style. In the science style, stylistic accentuation categories are made on the basis oflexical linguistic units and phrases with the exclamation markaimed at drawing the attention of addressee. Accentuation categories in science texts amplify clarification, reinforcement, evaluation, and comparison value. Clarification is often shown by lexical-grammatical and syntactic accentuators (link-words, nouns, parenthetical words). For example: Changes in the weather are dependent on specific developments occurring in the atmosphere. Namely, the inclination of the earth axis totheorbital plane and its rotation around the Sun cause the change of seasons. (From textbook)

Under the sea,lightnings have increased;flashes have increased. These lightnings show all the fishes the direction and the path of the great journey. (From textbook)

The clarification valueof the stylistic accentuation category is often found in science texts. They use link-words like but, however, and, in this regard, nevertheless to deliver the importance of issues and news givento the readerin science texts.

The reinforcement value of the stylistic accentuation category is expressed by lexical-grammatical accentuators like very, particularly, especially, extremely, (the) most, -est. For example: Babylon was the most famous and largest city in Asia. Merchants brought goods from all over the worldthere. (From textbook)

Also, the reinforcement value of the stylistic accentuation category is shown by syntax and graphic symbols (italics, quotation marks and brackets in a sentence, underlining and semantic stress). "A text telling the story in the sequence of events is called a narrative. These sentences mean action.»(From textbook)

The values of the above-mentioned stylistic accentuation category are presented in the works by Professor D.Alkebaeva as microfields of accentuation categories in the science style. They include: evidencing, clarification, evaluation, category, activity etc. (Alkebaeva, 2014:38)

\section{Experiment}

Stylistic accentuation categories are clearly reflected in the texts of science style. However, they can be spotted in art texts too. In this regard, the story by the famous writer Oralkhan Bokey «The Tractor Man of a Graduate Girl» and the story by Mukhtar Anarbek «The Fate of a Beautiful Girl» were analyzed. The first story is about 10 to 11 pages. The latter is about 15 pages long. The title of both authors' stories has the stylistic accentuation category. Even without knowing the plot, the reader takes notice ofwor combinations like "Graduate Girl» and «Beautiful Girl» and immediately recognizes that further events willdefinitely develop around them.

There are many examples of stylistic accentuation in the story by Oralkhan Bokey. The story is understandableto the addressee and written in an easyto-readmanner. The writer advantageouslyused the stylistic accentuation category to 'unpack' concepts likelife, sadness, love, goodness, loyal person, and world. "In my opinion, he is not a bad guy excepting hisslight selfishness.

- Why shouldweexcept his selfishness? Kalkash said raising her voice like she received an answer. - "Ourbiggest mistake is to ignore his biggest flaw. I think he's the worst guy.»

"- Sadness?... Sadness... I believe it's the opposite of joy.

"In my opinion, sadness is a companion of joy or it can be said even its spouse. It warns against wrong action and silly mistakes. I never thought that it would havesuch a power. "

«It's not peoplemaking us toadmit mistakes, but time.»

"I dream of stealing you away of Almaty in a white horse-drawn white sledge whirling-up skyhighthe powder of that white world.» 
"Please tell me, - she said in a low voice, -have you ever loved someone?

- No.

- Lucky you.»

"Is life about tirelessly pushing on? No-no, life is aboutdiving into the memories of the pastonce in a while. Yesterday is tomorrow.»

"There are so many good people among us. Alas, we overlook them; we ignore them even knowing they are good.»

"I wasn't wrong, you are loyal, that is why you may often have had a bad luck... Let's sleep.»

In «The Fate of a Beautiful Girl»by Mukhtar Anarbek,we have found a lot of examples related to the stylistic accentuation category. The author effectively used the stylistic accentuation category to describe the girl's appearance and her inner thoughts. Stylistic connotations prevail over the stylistic accentuation category.

"No matter what you say, but summer is summer; a ray of the blazing Sun,sharp like a sword blade, passes straight ahead through the palm-like leaves of a tree to plunge into your head.»»Indeed, your hero from Qarqara has sweated so much that his shoulders look like a pair of shovels. Anyway, he is from Arqa with cold summersand long winters; since arrival his stuggles tocope with the glazing heat of Almaty.» Generally, all universityentering students are day-dreamers, aren't they? To be honest, I have a daydream too. I was scared to death to be recognized by them. But, lucky for me, thelovers pretended not noticing us, even if they did, and stepped into the darkness kingdom, and suddenly disappeared. However, their ringing voices were still heard. "They are not shy like we are...»»In the arms of mountain peaks with their nose in the air and their shoulders exposed for sun strokes, I, like a brave-heart who managed to pick an edelweiss, kissed a nymph-like girl for the first time in my life. It was my first love."In very deed, everyone was interested to know which one of us was the happy one. I want to safekeepthe beautiful girlhood image of her.» Rest in peace, Raikhan! I dedicate this note to you. Now, you will live forever! ... Many years lined-up like caravans have passed. I tried to forget everything. I got married. However, it is impossible to forget Raikhan, who gave me the gift of first childhood love. "The fair-skinned onein the middle of a group of girls looking like many-colored spring flowers especially caught my eye.» (Mukhtar Anarbek, https://adebiportal.kz/kz/blogs/view/2267)

\section{Findings and discussion}

The stylistic accentuation categories are encountered in the analyzed works of art. The age difference between Oralkhan Bokey and Mukhtar Anarbek is approximately 24 years. For example, «The Tractor Man of a Graduate Girl» describes the 1971s, while «The Fate of a Beautiful Girl» refers to 1985-86. Two different social and political situations, the fate of two different girls were able to be the leading idea of those works. The style of both authors is different too. Oralkhan Bokey gravitate towards predominantly philosophical reflexion, while Mukhtar Anarbek's novel is full of lyrical melismate and descriptions. The only reason for this is that Oralkhan wrote his work when he was about thirty, and Mukhtar Anarbek's did the same at his 18-20. Both authors made their stories lightweight and impressive for the addressee. Oralkhan used stylistic accentuation categoriesmore efficiently than the second author to deliver a few vital and philosophical concepts. The master of the word tells the whole story from the moment of entering girl's tiny room. The story is told through a dialogue between two people. The reader is excited with the story line. Itleaves the impression of finding the key to a mystery, a secret, and completely reveals the characters' inner world.

In conveying stylistic accentuation categories, Oralkhan Bokey usedllinguistic units like too, (to) turn out to be, mean, such. The concepts of time, white world, sadness, selfishness, misery, life, loyaltyaregiven based on the stylistic accentuation category.

Stylistic accentuation categories are created using address (In my opinion), amplification adverbs (too, very special), demonstrative pronouns (that), question mark, multiple dots, dashes, modal words (it turned out to be). There are many stylistic accentuation categories in the dialogues between two characters.

At the same time, the story by Mukhtar Anarbek narrates feelings of the character and her attitude to other people around her based on a beautiful storyline. Apart from stylistic accentuation categories, there are a lot of stylistic connotations. There is no hidden motive. Only impressive narration of youth and student days inspired by the array of feelings. Thecommon thread for both stories is eternal love thatmakes the world go around. The first story is about neglected love and the other is about lovers parted by the twists of fate. In both stories, the char- 
acters are regrettable: one sees love divine and the other turns his love into the never-dyingfirst childhood love.

The stylistic accentuation categories in the story are noticeable throughhowever, such, indeed, in fact, it turned out to be, special, that, thislexical linguistic units. The author used childhood love, a happy person, daydreamer studentto highlight stylistic accentuation categoryfor the reader.

\section{Conclusion}

Like other branches of linguistics, stylistics also has its own categories. Stylistic categories are not fully studied at the required level and still require research. This article deals with stylistic accentuation categories. Stylistic accentuation categories have been proven to be found in all functional styles. Stylistic accentuation categories require attention from meaning perspective of linguistic units; they show the addressee the reliability of author's vision, thereby ensuring that the recipient and the listener have a common understanding.
The stylistic accentuation categories are created in each style through their peculiar stylistic linguistic units. In addition, the stylistic accentuation categoriesgiven vialinguistic units perform different functions in every single style. But it was found that lexical linguistic units are important in all styles.

The microfields and theory of the stylistic accentuation categories are disclosed around the science style. Science texts were widely analyzed. However, in the analysis of art works, it has been proved that the stylistic accentuation category is encounterable. Stylistic accentuation categories in art texts are made by elements of lexical language, such as amplification adverbs, address, modal words, and punctuation. They are especially frequent in dialogues and paragraphs. In summary, it may be claimed that stylistic categories play an important role in creating arttexts. The author ensures a complete connection between the reader, the addressee and the addresser. The stylistic accentuation category plays an important role in determining the core of ideas and thoughts.

\section{Әдебиеттер}

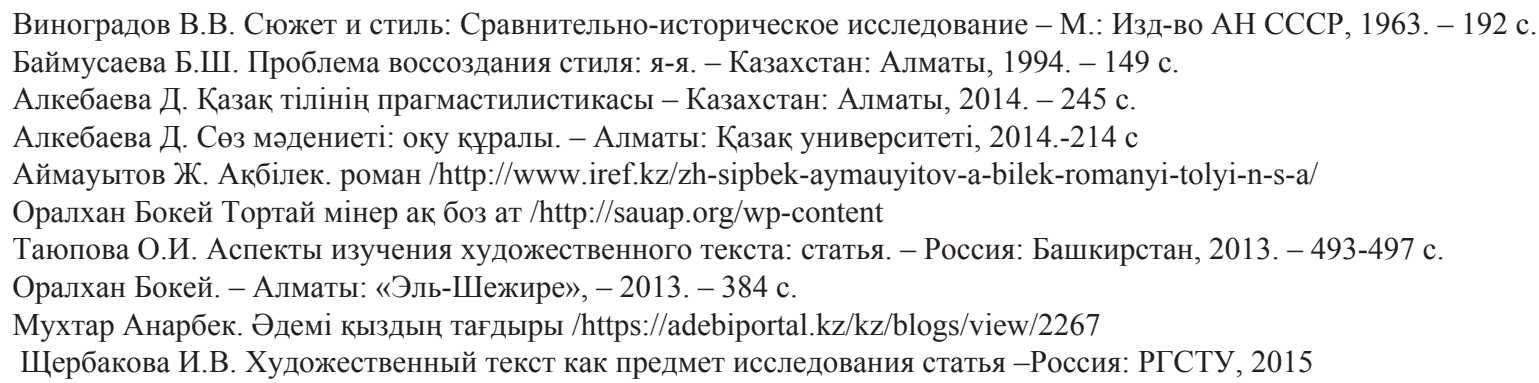

\section{References}

Alkebaeva D. (2014) Qazaq tilinin pragmastilistikasi: oqylyq [Pragmastilistic of the Kazakh language]. - Qazaqstan: Almaty, 245 p. (in Kazakh)

Alkebaeva D. (2014) Soz madeniety: oku kyraly [Culture of speech]. - Almaty: Kazakh Universiteti, 214 p. (In Kazakh)

Baymysaeva B.Sh. (1994) Problema vossozdaniya stilya: dis-ya [Problem of recreating style]. - Qazaqstan: Almaty, 149 p. (in Russian)

J.Aimauytov Aqbilek [novel Aqbilek] /http://www.iref.kz/zh-sipbek-aymauyitov-a-bilek-romanyi-tolyi-n-s-a/ (In Kazakh)

Mukhtar Anarbek Ademi qyzdyn tagdyry povest [story The fate of a beautiful girl] https://adebiportal.kz/kz/blogs/view/2267 (in Kazakh)

Oralhan Bokei. (2013) - Almaty: «El-shejire», 384 p.(in Kazakh)

Oralhan Bokei (2013) Tortai miner ak boz at [story Tortai miner ak boz at] /http://sauap.org/wp-content (in Kazakh)

Tayupova O.I. (2013) Aspekty izycheniya hydojestvennogo teksta: statia [Aspects of the study of litrery text]. - Rossia: Bashqyrstan, 493-497 p.(in Russian)

Vinogradov V.V. (1963) Siyjet i stil: sravnitelno-istiricheskaia issledovanie [Plot and style: comparative historical study]- M. : Izd - AN SSSR, - 192 p.(in Russian)

Sherbakova I.V.(2015) Hudojestvennyi tekst kaka predmet issledovania: statia [Artistic text as a subject of study]. - Rossia: RGSTU .(in Russian) 